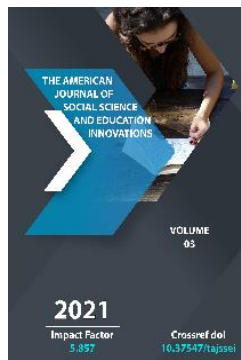

\title{
Translation Of Occasional Words -Author's Neologisms In Harry Potter (English Into Uzbek)
}

\author{
Mehriniso Murodjon Qizi Abduraimova \\ Teacher, Teaching English Language Methodology Department, Uzbekistan State World \\ Languages University, Uzbekistan
}

\begin{abstract}
Journal Website: http://usajournalshub.c om/index,php/tajssei

Copyright: Original content from this work may be used under the terms of the creative commons attributes 4.0 licence.
\end{abstract}

\section{ABSTRACT}

The aim of this article is to examine the specific vocabulary of Joanna Rowling's Harry Potter book series, to address issues with translating the author's neologisms, and to propose alternative methods. Furthermore, to compare the Uzbek translation of the work to the original, to recognize inconsistencies and problems in translation are also in the center of discussion. The author's neologisms are also examined in terms of their types, structure, and content. The methods of translating newly coined words will be considered, depending on the content and style of their production.

\section{KEYWORDS}

Occasional words, author's neologisms, semantic derivation, word acquisition, compositon, affixation, transliteration, transcription, phonetic adaptation, localization, lexical-semantic transformation.

\section{INTRODUCTION}

It is mentioned a lot that Joanna Rowling became the author of great amount of new words while creating the unique world, environment, and language language of Harry Potter world. As we know, the words created by an author and related only to his works, 
which are not used in everyday life, are called occasional words. Such words are also called author's neologisms (Choriyev B., 1994). Nowadays we have the term "potterisms" to mention group of words that are typical for Harry Potter book series. Occasionalism is characterized by its novelty, uniqueness and attention to detail. They are the ability of the writer to express his thoughts and goals in a unique way, to express the person's feelings, things, events described in all its aspects, and to express his attitude to them, that is, his feelings, they are created for the purpose of vivid expression (Tukhtasinova O.Y, 2007). They usually occur when the language's ability to describe an object does not satisfy the writer or speaker. In this regard, it is not difficult to imagine how much creativity from Joanna Rowling was required to create the attributes of the fantasy world - the world of magic.

Author's neologisms make up a significant part in Harry Potter's vocabulary. Obviously, author's neologisms are considered to be extraordinary, randomly created words. But the new words in this work are systematically created based on a certain purpose, which includes spells, place names belonging to the magical world, objects, fantastic animals and characters, plants, food, wizards' habits and social groups. The semantics of such occasional words are very important for the translator, because it takes a lot of effort to understand the meanings they contain.

\section{MAIN PART}

Joanna Rowling so skillfully expressed the units in Harry Potter world that their content, resonance, and uniqueness have made translators think about them over and over again. The world of magic she created has its own structure and associations - a political and economic system, a system of government and education, as well as professions. It is very important to classify such a new lexicon created by the writer. Because their translation may also require special approaches depending on the type. In analyzing the semantics of the neologisms created by the author in this work and thinking about the peculiarities of their translation, we divide them into the following groups:

- $\quad$ Toponyms;

- $\quad$ Proper names;

- Names of magical creatures;

- $\quad$ Magical items;

- $\quad$ Food names;

- Spells;

- Herbs and tinctures:

- Abbreviations;

- Social groups;

- And the group of words related to the culture of magicians and their behavior.

Apparently, this classification itself determines the weight of the author's neologisms. In the process of giving examples to each of them, we mainly referred to the first part of the work, "Harry Potter and the Philosopher's Stone".

Before we talk about the translation process of objects typical of the world of Harry Potter, first of all, it is necessary to dwell on the translation of the magical world and the place where all those magical words are used. Of course, it would be a good idea to start with Hogwarts, the school of witchcraft and wizardry. The word "hogwarts" is considered by many translators and fans of the work to be a compound word, while "hog" is derived from the words "wild boar" ( yovvoyi to'ng'iz) and "warts"(so'gal) is derived from the word "wart". As an explanation for this we can cite 
several translations of this name. For example, French version - "Poudlard" ("pou du lard") means “to'ng'iz burgasi” (flea of a boar). In Hungarian, "Roxfort" is a mixture of the words "roquefort" (cheese with big holes in it) and "Oxford". Interestingly, the author herself gives an idea in her interviews that the origin of the word does not come close to the above given meanings, that is, the "hogwort" was a plant she unknowingly encountered several years before the work was written, in scientific language it is called "croton capitatus". This proves that the name given to the school of wizards is not related to the name of any animal. Although Joanna Rowling has suggested that the name may have been chosen inadvertently, she has attached a certain meaning to the word throughout the work. The following is an excerpt from the Hogwarts Anthem:

“Hogwarts, Hogwarts, Hoggy Warty Hogwarts

Teach us something please"

We know that in English the suffix "-y" creates adjectives: rain-y, shine-shiny, mess-y. Here, too, the words hog and wart have become adjectives through this suffix. But they don't mean "pig" or "wart" because such qualities do not apply to the name of places. When analyzing made-up words in a foreign language, it is possible to cite a number of variants in the translation at the expense of the units that make them up. For example, parts of the word Hogwarts have secondary meanings: hog (verb) - to use alone what should be shared; greedy man; and wart - meaning wrong and unpleasant habits. If we analyze it based on the additional meanings given, we can see that the word Hogwarts has a complex and deep meaning. That is, not everyone is fortunate enough to study in this school of magic, during the years, students in the school face many difficulties, and the school itself has secrets that are not known to students, even to the teachers themselves. For example, Mirror of Erised, Chamber of Secrets, Hidden Corridors and passages, Room of Requirement and etc.

In almost all translations, Hogwarts is phonetically adapted to target languages and the pronunciation is preserved as much as possible: in Russian - Хогвартс, in Bulgarian - Хогуортс, in Spanish - Hogwarts, and so on. We also decided to transcript them as "Hogvarts" and give the word its original pronunciation in support of their approach.

There are also a number of recurring place names in the work. For example, Diagon Alley and Knockturn Alley. The author uses word play in the use of these words, i.e. the word "Diagon alley" is pronounced almost the same as the word "diagonally" which means "crooked, confused" in English. The place itself is made up of narrow, sloping, winding streets. This word is translated "Косой переулок" in Russian. In Uzbek, we meet in the form of "Diagon hiyoboni (alley)". In contrast to the Russian translation, the Uzbek place name has lost its connection with its appearance. In order not to repeat this shortcoming, we can translate the name in the form "Qiyshiq hiyobon" in accordance with its content.

\section{RESULTS AND DISCUSSION}

When translating author's neologisms, it is important to pay attention to which word group they belong and which way they are formed. Given that author neologisms belong to different word families, they can be created in three main ways: through affixes, through semantic derivation, and through word acquisition. (Skrilnik A.V, 2017) 
The word "sneakoscope" is formed by adding the suffix "-scope" to the word "sneak" and means a tracking, searching or measuring device such as a microscope, telescope. The word "sneak" means "to act secretly, to speak secretly" in English. In the literary work, this object is used to find dangerous people hiding, it makes a noise to the owner and warn him that someone is walking around. That is, it reveals the secrets of someone with bad intentions. Based on this information, the word "sneakoscope" is translated into Russian as "вредноскоп" ("ROSMEN"), and in Uzbek we can see a similarity in content - "ofatskop".

The next neologism "omnioculars" have the same structure as the word binoculars in real life, and are a kind of binoculars used by magicians. We know that "ocular" is a word in the adjective category, meaning "related to the eye or sight." The prefix "omni-" gives the word meanings of "many, unlimited" (“ko'p, chegarasiz, son-sanoqsiz") (Cambridge dictionary). This, "omniocular" is a type of binoculars which is used to observe Quidditch games in wizarding world, and it differs from ordinary binoculars by a number of additional features. For example, slowing down or repeating actions:

"Omnioculars," said the sales-wizard eagerly. "You can replay action... slow everything down... and they flash up a play-by- play breakdown if you need it.

“Келинг, омниокулярдан олиб қолинг! ғайрат-ла таклиф қилди сотувчи, - Қаранг, омниокулярнинг кузатилаётган вазиятни такроран кўриш... харакат суръатини секинлатиш... имкониятлари бор."(taken from translation of Sh. Zokirovich)
As we can see, in Sh. Zokirovich's translation, the word was only transliterated, because the same method was used in the Russian translation, which was the source text for the translator-“омнинокль”

(«РОСМЭН» Publishing House). The emphasis here was on the prefix "omni" and it would be appropriate to replace it with existing suffixes in the language being translated. That's why we decided to use the word "Ko'poynakli" ( "ko'p" - "many", “oynak"_ “glass") in our translation.

“Bular Ko’poynaklilar,” dedi sehrgar sotuvchi ishtiyoq bilan. "Uning yordamida voqelarni takroran ko'rishingiz...harakatlarni sekinlashtirishingiz... va xattoki kerak paytda o'yinni alohida qismlarga bo'lib ko'rishingiz ham mumkin.

The most famous and interesting of Joanna Rowling's neologisms are, of course, the names of sweets and drinks that exist only in the world of magic. Their diversity and unique features amaze not only children but also adult readers. While creating them, author puts more emphasis on resonance than other types of new words. In this words we can find repetition, alliteration, and sequence of similar sounds. For example, Butter Beer, Fainting Fancies, Fizzing Whizzbees, Pumpkin Pasties, Ton-Tongue Toffee and more. Consequently, translators will have an additional responsibility to maintain the tone of their words. We have tried to translate these neologisms preserving the sound resonance as much as possible: 
The American Journal of Social Science and Education Innovations

(ISSN - 2689-100x)

Published: April 30, 2021 | Pages: 292-298

Doi : https://doi.org/10.37547/tajssei/Volume03Issue04-43

2021: 5.857

OCLC - 1121105668

\begin{tabular}{|c|c|}
\hline Bertie Bott's Every Flavour Beans & Berti Botning turli tám'mli loviyalari \\
\hline Skiving Snackboxes & Dangasaning gazaklari \\
\hline Fainting Fancies & $\underline{\text { Xushdan ketiruvchi xushtamlar }}$ \\
\hline Ton-Tongue Toffee & Til o'stiruvchi toffilar \\
\hline Canary Creams & Kanareyka kremlari \\
\hline Fudge Flies & Shirin pashshalar \\
\hline
\end{tabular}

Certainly, while translating the above given words into Uzbek, we used their descriptions in the work. We also used the modulation method, focusing on synonyms or adjectives of existing words in generating sound repetition and alliteration. For instance, Skiving Snackboxes. It is a collection of sweets and pastries that students use to find excuses to drop out of class. The word "skive" itself means "to avoid work or to leave without permission." In addition to the meaning of the word, its function also taken into consideration and we have translated it as "dangasaning gazaklari".

The same can be said of Fudge Flies, a soft fudge that is presented in the form of a fly. Since the main focus is on its shape, we decided to change the word "fudge" into "sweet"("shirin") and create a repetition of the consonant "sh" in Uzbek language. Similarly, if we look at all of the above examples, the names of sweets are all made up of words that are common in everyday life. But why they are called "new"? Because they became completely new along with the words that come together and they created new images. Take, for example, beers, cakes, caramels, which represent new ideas, such as Butter beer-qaymoqli musallas, root beerildizli musallas, Couldron cakes-qozoncha kekslar, Caramel cobwebs-karamelli o'rgimchak to'ri and etc.
As for the next type of occasionalism, they are social groups living in the world of magic. Examples include Muggle, Healer, Animagus, Metamorphmagus, Squib, Auror, Death-Eater. Their methods of construction are also different: morphological (affixation), syntactic (composition), semantic, word acquisition methods. For example, the words Muggle and Obliviator are formed by affixation. Muggle is the name given to a non-magical people in the work, which was coined by Joanna Rowling and according to the Oxford Online Dictionary the word "mug" was used as its core. "Mug" is a polysemantic word that means "ovsar, o'ta ishonuvchan" ("stupid, credulous"). Author describes that muggles are tend to believe each and every unusual things and activities occuring around them were the miracle of the nature and their lifestyle also remarkably unfamiliar to the wizardkind: "although it goes without saying that foolishness or stupidity is not a hallmark of Muggles "(soddalik va ahmoqlik Magllarga begona emaslgini aytib o'tishga xojat yo'q). Here, a new word has been created with the help of the adjective -le and translated with the method of transcription. Another word "obliviator" is formed by adding a suffix "-ator" to the word "oblivion". Wizards with this title are mainly engaged in erasing the memory of ordinary people who witnessed the process of using magic or a spell. 
Examples of compositional words are Metamorphmagus, Animagus, and DeathEater. The first two words apply to wizards who can change their form or appearance. The word "metamorph" is a term used in scientific language to describe the transformation of a plant or insect into another form. By adding the main syllable of the word "magic" and the Latin suffix"-us" to this word, it gained the following meanings: "shakl o'zgartiruvchi afsundan foydalana oladiganlar" yoki "ko'rinishini o'zgartiruvchi sehrgarlar" ("those who can use a transforming spell" or "magicians who change their appearance"). There is another type of magician in this group, which, unlike metamorphmagus, can only take the form of an animal. The name given to them is "animagus", which is based on the word "animal". So both words are made up of both composition and affixation. We translated them "metamorfamaglar" and "animaglar" through transliteration and phonetic adaptation.

Joanna Rowling is known to have based much of her new lexicon on Latin. Next word that refers to the another type of social status "Auror" is also derived from Latin and means "gold, related to gold." Given the value of gold among metals, this so-called group of magicians is also a team that fights against evil magicians who have the deepest knowledge in the field of magic, who are superior to other magicians. We can learn this from the following passage:

"You're an Auror?" said Harry, impressed. Being a Dark-wizard-catcher was the only career he'd ever considered after Hogwarts.

- Сиз аврормисиз? - сўради кучли таъсирланган Гарри. Аврор, яъни ёвуз сехргарларга қарши курашадиган агент касби болани қизиқтирган ягона касб эди.

Here, this word is transcripted into Russian and Uzbek. However, we decided to modulate the word as "Jangchi afsungarlar"(Warrior Wizards), keeping in mind that the profession of "Aurors" is similar to that of law enforcement officers in real life, and that in the most difficult situations they act first.

"Siz Jangchi afsungarmisiz?", hayrat bilan so'radi Garri. Yovuz-sehrgarlarni-tutish bilan shug'ullanish maktabni tugatganidan keyin u egallashni xohlagan yagona kasb edi.

\section{CONCLUSION}

The writer created a magical world in harmony with the real world, making effective use of the possibilities of language. The universe she created has its own magical beings - plants, supernatural objects and habitats, unique social groups - cultures and customs. And, of course, the new words are all considered as occasionalisms. The ways of making occasionalisms discussed above prove that Joanna Rowling made extensive use of both productive and non-productive word-froming techniques in creating her neologisms: through additions, composition, change of meaning, borrowing. While the creation of neologisms is the result of the creative use of language, their translation requires the same effort. An indepth study of the content of words and a full understanding of the context that goes into them paves the way for perfection in their translation. Taking into account the type and construction of each neologism, its content, in the translation process we can use methods of transliteration and transcription, phonetic adaptation, localization, as well as modulation, which is the technique of lexical-semantic transformation. Working with such words 
allows translators to increase their knowledge in both source and target languages, and sometimes translators have the chance to refer to additional languages, to make proper use of existing word-formation techniques, and, if necessary, to encourage the creation of new words in target language.

\section{REFERENCES}

1. Choriyev B. G'afur G'ulom she'riyati tili.-T.:Fan, 1994

2. Skrilnik A.V. Способы образования авторских неологизмов в английском языке на материале книг Дж. К. Роулинг// Филологические науки. Вопросы теории и практики.Тамбов.: Грамота, $2017 . \quad$ № 7(73):www.gramota.net/materials/2/2 017/7-1/41.html

3. To'xtasinova O.Y.,O'zbek tilida leksik okkazionalizmlar va ularning badiiyestetik xususiyatlari:

Filol.fanl.nomz...diss.-Toshkent, 2007.

4. Rouling.J.K. Garri Potter va Faylasuf toshi.—T :2018

5. Rouling.J.K. Garri Potter va Sirli xona.-T.: 2018

6. Rowling, J.K. Harry Potter and the Philosopher's stone. - London: Bloomsbury Publishing Plc, 2013

7. Rowling J.K. Harry Potter and the Order of Phoneix. - London: Bloomsbury Publishing Plc, 2013.

8. Ролинг Ж.К. Гарри Поттер и Кубок огня: Роман/ Пер.с англ Й.В.Оранского.-Москва: ЗАО “РОСМЕН-ПРЕСС",2012.

9. Ролинг Ж.К. Гарри Поттер и философский камень: Роман/ Пер.с англ Й.В.Оранского.-Москва: ЗАО “РОСМЕН-ПРЕСС”,2012.-400 С.
10. Cambridge Avanced Learner's Dictionary, Third edition, Cambridge University Press, 2008.

11. Rasuljanovna, I. N. (2020). The concept of "lacuna" in translation studies. Asian Journal of Multidimensional Research (AJMR), 9(4), 123-129.

12. Khudoyorovich, K. K., Rasuljanovna, I. N., Khalmuratovna, R. Z., \& Eshkobilovna, K. D. (2020). The Issues of Word Choice in Fiction Translation. International Journal of Psychosocial Rehabilitation, 24(04). 